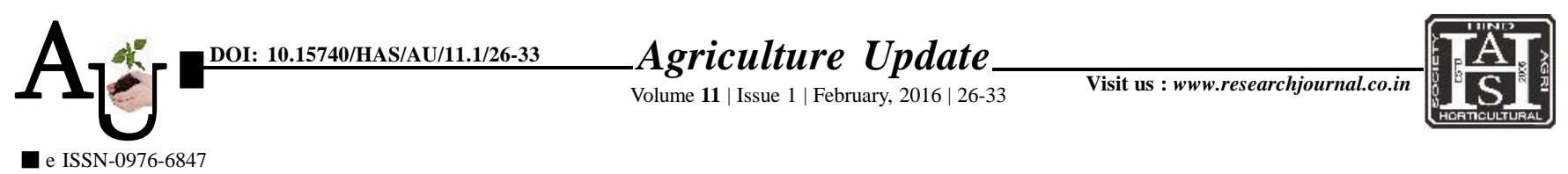

\title{
Research ARticle: Workload of women in conventional and organic farming in the selected agro-climatic zones of northern Karnataka
}

Article Chronicle:

Received :

13.06.2015;

Revised :

26.12.2015;

Accepted :

11.01.2016

KEY WoRds:

Workload,

Agro-climatic zones,

Organic farming

Author for correspondence :

\section{RAJESHWARI DESAI}

Extension Education

Unit (UAS), GADAG

(KARNATAKA) INDIA

Email:rajmanohardesaiuas

@ gmail.com

See end of the article for

authors' affiliations
SUMMARY : Women play a predominant role in almost all agricultural operations as well in organic farming. Organic farming is women oriented as they do most of the operations like cleaning the seeds for sowing, transplanting, weeding, harvesting, threshing, winnowing and seed preservation. All these are done with an admirable patience and commitment. Hence the present study was conducted with the objective to study the participation level and delineate the areas of participation of women in organic and conventional farming. The results revealed that irrespective of the agro- climatic zones, among both organic and conventional farming practices, the sole participation of women was observed in performance of value added products. Women dominance was observed among the organic farm women for seed activities also for harvesting, threshing and processing activities for both organic and conventional farm women. The sole performance of men to dominance of men in the performance of the activities was seen in performance of irrigation and marketing activities. The work load of organic farm women with respect to seed activities, sowing, after care operations and threshing and processing activities was more when compared to conventional farm women and was found to be statistically significant at one per cent level. The higher involvement of conventional farm women was found with respect to preparatory tillage activities to that of organic farm women and was found to be statistically significant. The work load of both organic and conventional farming families was almost equal with respect to irrigation, harvesting, marketing and preparation of value added products.

How to cite this article : Desai, Rajeshwari and Sumangala, P.R. (2016). Workload of women in conventional and organic farming in the selected agro-climatic zones of northern Karnataka. Agric. Update, 11(1): 26-33. 